\title{
ПРИНЦИПИ ТА ЛОГІКА ПОБУДОВИ БАЗИ ЗНАНЬ 3 ДОПОМІЖНИХ РЕПРОДУКТИВНИХ ТЕХНОЛОГІЙ
}

\author{
С. В. Денисенко
}

Національна медична академія післядипломної освіти імені П. Л. Шупика

\begin{abstract}
У статті розглянуто можливості створення онтології знань із проблеми безпліддя та використання допоміжних репродуктивних технологій (ДРТ). Підкреслюється думка, що важливо забезпечити системне вирішення клінічних завдань. У цьому випадку загальні знання про захворювання повинні бути представлені багаторівневою моделлю. При цьому базова площина стану є базою всіх знань, накопичених до даного часу. Решта площини графра цілеорієнтовані та пов'язані з технологічними процесами в клініці: діагностика патологічних процесів, оцінювання стану пацієнта, прогнозування результатів ДРТ тощо.
\end{abstract}

Ключові слова: допоміжні репродуктивні технології, онтологія знань, база знань, багатовимірні онтологічні моделі.

\section{ПРИНЦИПЫ И ЛОГИКА ПОСТРОЕНИЯ БАЗЫ ЗНАНИЙ ПО ВСПОМОГАТЕЛЬНЫМ РЕПРОДУКТИВНЫМ ТЕХНОЛОГИЯМ}

\author{
Национальная медицинская академия последипломного \\ имени П. Л. Шупика
}

С. В. Денисенко

\begin{abstract}
В статье рассмотрены возможности создания онтологии знаний в проблеме бесплодия и использования вспомогательных репродуктивных технологий (ВРТ). Подчеркивается мысль, что важно обеспечить системное решение клинических задач. В этом случае общие знания о заболевании должны быть представлены многоуровневой моделью. При этом базовая плоскость состояния является базой всех знаний, накопленных к данному моменту времени. Остальные плоскости графа являются целеориентированными и связаны с технологическими процессами в клинике: диагностика патологических процессов, оценка состояния пациента, прогнозирование исходов ВРТ и т.д.
\end{abstract}

Ключевые слова: вспомогательные репродуктивные технологии, онтология знаний, база знаний, многомерные онтологические модели.

\section{PRINCIPLES AND LOGIC OF THE KNOWLEDGE BASE ON ASSISTED REPRODUCTIVE TECHNOLOGY}

\section{S. V. Denysenko}

National Medical Academy of Postgraduate Education by P. L. Shupyk

\begin{abstract}
The article discusses the possibility of creating an ontology knowledge in a problem of infertility and assisted reproductive technologies (ART) using. Emphasizes the idea that it is essential that the system solution of clinical problems. In this case, the general knowledge about the disease should be submitted to the multilevel model. In this case, the reference plane is the base of all the state of knowledge accumulated to this point in time. The rest of the plane graph are goal-oriented and process related to the clinic: diagnosis of pathological processes, patient assessment, prediction ART outcomes, etc.
\end{abstract}

Key words: assisted reproductive technologies, ontology knowledge, the base of knowledge, multidimensional ontology models.

Вступ. Фундаментальні дослідження в галузі репродукції людини привели до того, що 30 років тому була відкрита нова епоха в лікуванні безпліддя - епоха допоміжних репродуктивних технологій, що дозволили домогтися успіху великому числу подружніх пар, приречених на бездітність. Використання методів ДРТ для лікування безпліддя з максимальною результативністю, а також істотного скорочення непотрібних витрат на проведення тих чи інших процедур, пов'язана з реалізацією методів пошуку, розробки та 
систематизації критеріїв, що сприяють прогнозуванню ефективних шляхів досягнення вагітності при формах безпліддя, що зустрічаються найчастіше. Вважається, що нові підходи в стратегії пошуку чи розробки нових підходів може забезпечити застосування онтологій знань із проблеми безпліддя. Саме такий підхід забезпечується при створенні бібліотеки біомедичних онтологій, в якому узгоджено набір принципів, які узагальнюють кращі практики розробки онтологій. Ці принципи покликані сприяти інтероперабельності і забезпечити поступове підвищення якості та формальної строгості в подальшій розробці онтологій.

Мета роботи - формулювання засад створення онтології знань із проблем допоміжних репродуктивних технологій.

Результати та їх обговорення. Робота лікаря в практичній медицині формалізується за видами діяльності - діагностика, оцінювання стану, прогнозування, вибір методу лікування тощо. В принципі, всі ці види діяльності являють собою додатки систем штучного інтелекту, i їх застосування допомагає лікареві у професійній діяльності. Завданням таких систем є прийняття того чи іншого рішення, а їх необхідними компонентами служать показники довіри, обсяги знань, що є в інформаційній системі, та підсистема пояснення. Остання повинна роз'яснювати користувачеві, на основі яких міркувань і знань пропонуються ті чи інші рішення.

В даний час для вирішення клінічних завдань розробляються два класи систем, що розрізняються методами, покладеними в їх основу. Один клас складають системи, засновані на статистичних та інших математичних моделях - їх основою служать математичні алгоритми, що призначені для пошуку зазвичай часткової відповідності між клінічною картиною певного пацієнта та симптомами пацієнтів, які спостерігалися раніше та діагнози яких відомі [I]. Однак такі системи не завжди користуються довірою лікарів при поясненні отриманого результату.

Системи другого класу засновані на знаннях експертів. У них алгоритми оперують інформацією про пацієнта і знаннями про захворювання, представлені у формі, в тій чи іншій мірі наближеній до уявлень лікарів (і описаних експертами-лікарями), що досягається за рахунок явного або неявного використання онтологій медичної діагностики. Саме в системах такого типу можливе створення підсистем довіри, а також побудова компонента пояснення, здатного надати лікареві результати аналізу даних пацієнта, що привели до отриманого рішення завдання.
Використовувані в таких системах моделі онтології враховують зміну значень ознак у часі [I], зв'язку симптомів і захворювань (наприклад, за допомогою логічних правил) [2], кластеризацію спостережень на кілька груп (відповідно методам дослідження або групам діагнозів [4]).

Важливо не залежно від використовуваного алгоритму представити єдиний формат інформаційного забезпечення. У рамках такого єдиного підходу до структури онтології найефективніше, за даними літератури, використовувати графові моделі. У такому випадку властивості структури онтології визначаються в термінах відповідних графів через підрахунок числа вершин або дуг, числа однойменних дуг, розгалужень, числа і частки дуг із певними мітками тощо.

Алгоритми в кожному з завдань або імітують хід міркувань лікаря при встановленні діагнозу [7], займаються пошуком відповідності інформації про хворого і клінічних картин захворювань, описаних лікарем [9], або обробляють задані експертами правила, що описують зв'язки спостережень і захворювань [5].

Серед груп графів, які моделюють структуру онтологій у рамках єдиного підходу, виділяють групу графів синтаксичних зв'язків і групу графів стандартних зв'язків [3]. Вони можуть виявитися інформативними для узагальнення швидко зростаючих відомостей з оцінки стану, вибору методу корекції прогнозування результатів при екстракорпоральному заплідненні.

Для графів стандартних зв'язків характерно, що їх вершини відповідають термінам онтології (їх імена стають мітками вершин), а спрямовані дуги - стандартними видами зв'язків (типово вживаним при формалізації онтологій). Назви зв'язків складають кінцеву більшість уточнюючих «підвидів» стандартних зв'язків (вони можуть розглядатися як мітки для дуг) [3].

Нам здається, що моделювання патологічного процесу, як таке, практично повністю відсутнє в сучасних онтологічних моделях. Основний недолік теоретичних розробок, пов'язаних з моделюванням патологічного процесу пов'язаний з тим, що в більшості досліджень процес представляється як двомірний. Водночас характер клінічних завдань зовсім не припускає використання всього масиву інформації, накопиченої в медицині. Для кожної з розв'язуваних постановочних завдань, в принципі, використовується до 40-50 симптомів. Зрозуміло, завдань у клініці багато і загальний обсяг відомостей, необхідних для 
узагальнення, становить тисячі ознак, симптомів і симптомокомплексів.

Таким чином, лікар завжди бачить і використовує те, що відповідає конкретній задачі - діагностики, прогнозування і т.д. Водночас вкрай важливо забезпечити системне рішення клінічних завдань. У цьому випадку загальна модель знань про захворювання повинна бути представлена багаторівневою моделлю [6]. Саме в такому ключі повинна розвиватися проблематика штучного інтелекту.

Якщо розглядати можливість систем діагностики та прогнозування в проблемі безпліддя, треба відзначити їх крайню нечисленність. Крім того, використовувані в них онтології медичної діагностики є порівняно простими і водночас не відображають такі повсюдно використовувані лікарями в їх практиці знання предметної області як: знання про причини патологічних процесів, що лежать в основі безпліддя; знання про різні типи причинних зв'язків між ознаками і захворюваннями; знання про впливи подій на значення ознак при безплідді; знання про різні варіанти зміни значень ознак, що залежать від анатомо-фізіологічних особливостей пацієнтів тощо.

Крім цього, однією з негативних властивостей розроблюваних систем $\epsilon$ те, що можливості їх застосування невеликі. Це обумовлено тим, що вони являють собою або макетні версії, виконані для окремих дослідницьких цілей, або розроблені для певного медичного закладу і не доступні за рамками його локальної мережі. 3 іншого боку, системи медичної діагностики, що надають широкий доступ до своїх ресурсів із застосуванням сучасних мережевих технологій не дозволяють експертам розширювати використовувані в них бази знань.

Отже, актуальним завданням є розробка системи медичної діагностики, заснованої на знаннях експертів і моделі онтології, що враховує всі наведені вище особливості медичних знань, в якій їх модель має форму найбільш близьку до уявлень експертів і дозволяє не тільки визначати діагноз пацієнта, а й пояснювати його.

Така система повинна проводити розпізнавання процесу і вибір методу корекції за прийнятний для лікаря час і надавати доступ щодо великого числа користувачів як для вирішення медичних завдань, так i для участі в накопиченні та вдосконаленні медичних знань про різні захворювання.

Співвідношення між невідомими та параметрами поділили на кілька смислових груп, що визначають:

I) знання про причинно-наслідкові відносини і причинно-наслідкові зв'язки окремих симптомів патологічного процесу;
2) причинно-наслідкові зв'язки, що є причинами зміни функціонального стану організму;

3) межі інтервалів розбиття для кожної ознаки;

4) причини патологічних станів, що входять в діагHO3.

Кожне з типів співвідношень визначається самостійно та використовується в окремих алгоритмах.

Отже, ставиться спільне завдання розпізнавання можливих патологічних процесів у пацієнта на основі даних його обстеження (симптомів, анатомо-фізіологічних особливостей, анамнезу захворювання), а також знань предметної області. Крім того, для кожного стану пацієнта має бути сформовано етіопатогенез процесу.

У зв'язку з тим, що наведена модель онтології буде враховувати велике число зв'язків між процесами, що відбуваються в організмі пацієнта, можна очікувати, що алгоритм вирішення сформульованого вище завдання медичної діагностики, який аналізує всі ці зв'язки, матиме високу обчислювальну складність. Одним із шляхів підвищення ефективності такого алгоритму є його розпаралелювання та виконання на багатопроцесорній обчислювальній системі [3].

Найбільшого ефекту від розпаралелювання можна досягти при вирішенні практично важливої задачі, для якої ознаки можна аналізувати незалежно одна від одної (наприклад, при накладенні на використовувану модель онтології декількох обмежень). Це може означати, що у пацієнта фіксується лише один найбільш виражений (або найбільш важливий) патологічний процес і розглядається лише один його період розвитку.

Онтологія процесів діагностики станів при безплідді, яка нами розробляється, розглядається як багатовимірний граф. Базова (матрична) площина стану $є$ основою знань, накопичених до даного моменту часу. Інші площини графа є цільоорієнтованими і покликані вирішувати завдання діагностики патологічних процесів, оцінки стану пацієнта, прогнозування результатів ДРТ тощо.

Всього розглядається більше 300 вершин. Кожен конкретний випадок апостериорно досліджується в базі знань, і при виявленні нових станів або нових зв'язків, онтологія поповнюється відповідними відомостями. Передбачається статистичний аналіз частоти вершин і дуг (переходів). Зауважимо, що поповнення онтології новими вершинами і дугами здійснюється у всіх площинах багатовимірного графа.

Пілотні дослідження на архівних спостереженнях продемонстрували досить високу якість використання багатовимірної онтології. У задачах діагностики 
стану пацієнтів в архівних спостереженнях точність діагностики становила не менше $85 \%$. Інше дослідження ефективності подібної моделі онтології було пов'язано з оцінкою повноти подання знань. При комп'ютерному дослідженні 24 наукових і клінічних статей доповнень вершин і дуг знадобилося в 7-11\% випадків, що можна вважати хорошим результатом. Клінічне дослідження не проводилося до максимально можливого накопичення бази. Пороговими значеннями для прийняття рішень щодо клінічного застосування вважаємо досягнення 90-95 \% правильності діагностики та прогнозування стану у пацієнтів із безпліддям.

Висновки. 1. Сформульовано завдання розпізнавання можливих патологічних процесів у пацієнтів при

\section{Література}

1. Клещёв А. С. Модель онтологии предметной области «Медицинская диагностика». - Часть I. - Неформальное описание и определение базовых терминов /А. С. Клещёв, Ф. М. Москаленко, М. Ю. Черняховская // НТИ. Серия 2. 2005. - № 12. - С. 1-7.

2. Клещёв А. С. Модель онтологии предметной области «Медицинская диагностика». - Часть 2. - Формальное описание причинно-следственных связей, причин значений признаков и причин заболеваний /А. С. Клещёв, Ф. М. Москаленко, М. Ю. Черняховская // НТИ. Серия 2. - 2006. № 2. - C. 19-30.

3. Москаленко Ф. М. Задача медицинской диагностики и алгоритм её решения, допускающий распараллеливание / Ф. М. Москаленко // Информатика и системы управления. - 2005. - № 2 (10). - С. 52-63.

4. Москаленко Ф. М. Проект компьютерного банка знаний по медицинской диагностике / Ф. М. Москаленко // Информатика и системы управления. - 2007. - № 2 (14). C. 55-66. безплідді на основі даних їх обстеження (симптомів, анатомо-фізіологічних особливостей, анамнезу захворювання), а також знань предметної області. Для кожного стану пацієнта визначається структура етіопатогенезу процесу.

2. Онтологія процесів діагностики станів при безплідді розглядається як багатовимірний граф. Базова (матрична) площина стану є основою знань, накопичених до даного часу. Решта площини графа $€$ цілеорієнтованою і покликана вирішувати завдання діагностики патологічних процесів, оцінювання стану пацієнта, прогнозування результатів ДРТ тощо.

3. Проведено пілотні дослідження на архівних спостереженнях, що продемонстрували досить високу якість використання багатовимірної онтології.

5. Москаленко Ф. М. База наблюдений в области офтальмологии для банка медицинских знаний / Ф. М. Москаленко, М. Ю. Черняховская // Информатика и системы управления. - 2009. - № 2 (20). - С. 40-49.

6. Москаленко Ф. М. Формирование баз знаний о заболеваниях на основе онтологии медицины / Ф. М. Москаленко, М. Ю. Черняховская // Информатика и системы управления. Материалы III научной конференции «Системный анализ в медицине». - Благовещенск, 2009. - № 4 (22). C. $200-202$.

7. Хашаев 3. Х.-М. Онтологии медицинского знания с темпоральными аспектами / 3. Х.-М. Хашаев, Г. С. Плесневич, Э. М. Шекшеев // Фундаментальные исследования. - 2009. - № 2. - С. 51-55.

8. Плесневич Г. С. Бинарная модель знаний // III-й Международный научно-технический семинар «Интегрированные модели и мягкие вычисления в искусственном интеллекте». Сб. научных трудов (Коломна, май 2005). - М. : Физматлит, 2005. - Т. 1. - С. 106-117. 